\title{
Preparation of PDO mesh and research on its fabrication parameters
}

DOI: 10.35530/IT.070.03.1544

\section{Prepararea plasei PDO și studio privind parametrii de fabricare}

Folosirea protezelor pentru înlocuirea țesuturilor slăbite sau a fasciei pelvine este acceptată de mai mulți specialiști din domeniul medicinii actuale. PDO este, de asemenea, considerat un material degradabil ideal, cum ar fi PP, care a fost cel mai popular poplimer utilizat în domeniul medical. Studiul a pregătit o plasă PDO cu structură macroporoasă utilizând un model de placă armată cu structură poroasă de formă pătrată și materii prime din monofilamente PDO. Parametrii de fabricare, inclusiv diametrul monofilamentului, dimensiunea porilor, forma porilor, au fost analizate pe baza proprietăților mecanice adecvate ale plaselor PDO. Procesele optime de fabricație au fost obținute ulterior. Rezultatele au arătat că monofilamentele PDO cu diametrul de 0,23 mm ar putea face ca plasa să aibă propria greutate, grosime și rezistență la tracțiune, precum și cea mai mare forța de scoatere a suturii. Forma pătrată a porilor a întărit forța de tracțiune a plasei, menținând o forță mai mare de scoatere a suturii, în special în comparație cu forma de romb a porilor. În ceea ce privește dimensiunea porilor, plasa PDO cu pori de $5 \mathrm{~mm}$ a avut o rezistență mai mare, satisfăcând, de asemenea, necesitatea de greutate redusă a plasei. Degradarea in vitro a plasei PDO a fost măsurată folosind 3 monofilamente cu diametru diferit. Toate probele au fost degradate semnificativ numai după 10 săptămâni, rata de pierdere în greutate atingând aproximativ $30 \%$ după 16 săptămâni. În final, plasa PDO a fost evaluată pentru a avea un avantaj clar al greutății reduse, dar un risc scăzut de rezistență în comparație cu diverse alte tipuri de plasă comercializate.

Cuvinte-cheie: plasă medicală, PDO, parametrii de fabricare, proprități mecanice

\section{Preparation of PDO mesh and research on its fabrication parameters}

Using prosthesis to replace weaken tissues or fascia in pelvic is accepted by more people in present medicine field. PDO is also considered to be an ideal degradable material such as PP, which was the most popular used type in medical area. The paper prepared macro-porous structure PDO meshes using an armor plate model of square-pore structure and raw material of PDO monofilaments. Fabrication parameters including monofilament diameter, pore size, pore shape were discussed based on a suitable mechanical properties of PDO meshes. The optimal fabrication processes were obtained after then. The results revealed that PDO monofilaments of $0.23 \mathrm{~mm}$ diameter could make mesh to own moderate weight, thickness and tensile strength, as well as the largest suture pulling out force. Square-pore shape strengthened mesh tensile force, maintaining larger suture pulling out force especially compared to that of rhombus-pore shape. As for pore size, PDO mesh with $5 \mathrm{~mm}$ pores had larger strength, also satisfying requirement of mesh's lightweight. In vitro degradation of PDO mesh was measured using 3 different diameter monofilaments. All samples were significantly degraded only after 10 weeks, with weight loss rate reaching to about $30 \%$ after 16 weeks. Finally, PDO mesh was assessed to have an obvious lightweight advantage, but low strength risk by comparison to several commercial mesh products.

Keywords: medical mesh, PDO, fabrication parameter, mechanical property

\section{INTRODUCTION}

Pelvic floor dysfunction (PFD) covers diseases of pelvic organ prolapse and stress incontinence, with symptoms like metroptosis, vaginal wall bulge, defecation disorder. With the aging trend of the population in the world, senile diseases such as POP and SUI have a much higher morbidity. More than 50\% women over 50 years old are suffering from the diseases, with lifetime risk reaching to $30 \%$ to $50 \%$. PFD has a serious health risk to women, more than $11 \%$ of them even need to receive operation. Traditional surgery focused on repeatedly reinforced weak tissues, difficult to build a stable pelvic floor to resist the change of pressure. However, implanting mesh in pelvic area no more than repairs, but also brings weaken tissues to regeneration, reconstruct the whole pelvic floor and recover its anatomical structure.

With more advanced materials' wide clinical applications, reconstruction and repair of pelvic floor was improved greatly in recent years. Among various medical meshes, polypropylene (PP) is the most widely used type for its nice mechanical property and biocompatibility. PP material can be designed to several structures, leave a big part for product renewal. Also, it has good chemical stability which can live through the complex human internal environment. However, some defects of PP mesh such as hard hand-feeling and non-degradability, resulted in serious foreign body sensation, tissue adhesion and 
chronic infection [1, 2]. Moreover, PP mesh permanently existing in human body may immigrate into bladder after implantation longer than 5 years, lead to complications also. Recent research indicates that mesh is developing along a direction of lightweight, minimally invasive and being absorbable. In view of the high strength and degradability of Polydioxanone (PDO), the mesh is assumed to have advantages of light weight, low thickness, effectively reducing tissue adhesion and foreign body sensation [3-5]. The PDO material is not applied in medical mesh, but in other biomedical area. For example, Junyao Cai et al. prepared a mesh-structure stent reinforcement by hand braiding method, it is proved to have large porosity and good tensile property [6]. The high porosity is definitely an important character for improving mesh's application effect [7, 8].

This paper adopted 3 different diameter PDO monofilaments, braided to several mesh samples with different pore shape and pore size. The fabrication parameters were optimized based on measurements of tensile strength, bursting strength, bending stiffness and in vitro degradation property. The new type PDO mesh was also comprehensive evaluated by comparison to several commercial products, provided an experimental foundation for future study.

\section{EXPERIMENTAL WORK}

\section{Materials}

PDO monofilaments used for mesh preparation were provided by META BIOMED CO. LTD (Korea). The tensile property of monofilament was tested by YG(B)026G-500 electronic strength tester (Darong Textile Instruments Factory Co., Ltd, China) according to standard GB/T3923.1. The gauge between sample and chuck was $20 \mathrm{~mm}$, draw speed was 40 $\mathrm{mm} / \mathrm{min}$. The tensile property of PDO monofilaments was represented by breaking strength (cN/dtex) and elongation rate (\%).

The bending stiffness was measured by KES-FB2 ((KATO TECH, Japan). Twenty PDO monofilaments were parallel stuck to paperboard with grooves (figure 1). The samples were clamped between testing holder, drawn to curve in two directions with curvature from -2.5 to 2.5 . The bending stiffness $\left(\mathrm{N} \cdot \mathrm{mm}^{2}\right)$ of PDO monofilaments was obtained by sensor.

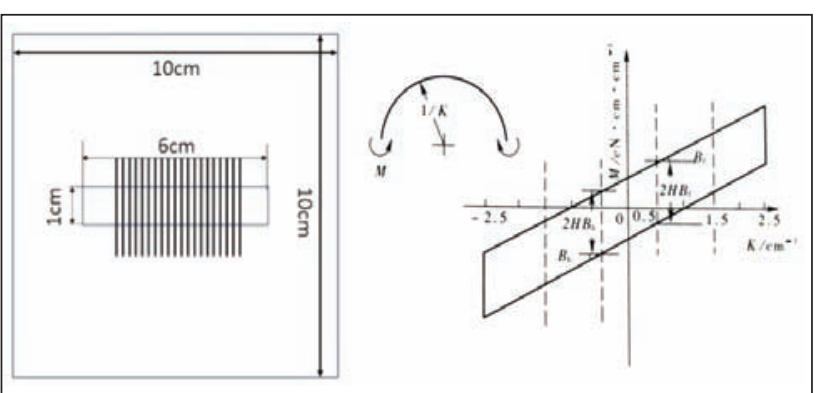

Fig. 1. Testing method (left) and principle (right) of bending stiffness

\section{Preparation of PDO mesh}

The PDO meshes were hand-braided using an armor plate model. PDO monofilaments run lengthwise and crossed at right angle to weft yarns. The weaving points were bond using medical adhesive bandage (Loctite, United States). The size of plate model was $15 \mathrm{~cm} \times 15 \mathrm{~cm}$ with grooves of $5 \mathrm{~mm} \times 5 \mathrm{~mm}$. Three types of PDO monofilaments $(0.16 \mathrm{~mm}, 0.23 \mathrm{~mm}$, $0.29 \mathrm{~mm}$ ) were adopted to prepare meshes with square-pore shape, designed into pore size of $5 \mathrm{~mm}$ and $10 \mathrm{~mm}$, respectively. The design structure of square-pore mesh was showed in figure 2 .

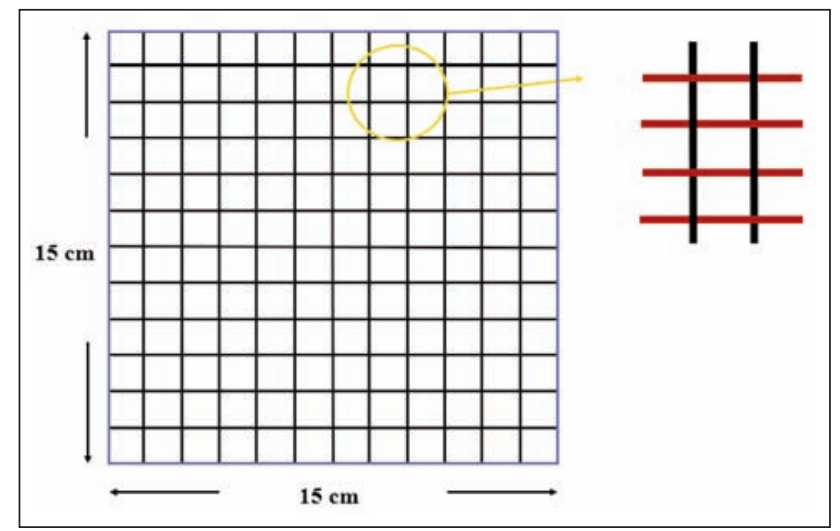

Fig. 2. Design Structure of square-pore PDO mesh

Then rotated plate mode was 45 degree, using the 3 types of PDO monofilaments to prepare rhombuspore PDO mesh, also under size of $5 \mathrm{~mm}$ and $10 \mathrm{~mm}$, respectively. The design structure of rhombus-pore PDO mesh was shown in figure 3 .

The braided mesh was heat-setting to obtain a permanent shape under temperature of $85^{\circ} \mathrm{C}$, time of

Table 1

\begin{tabular}{|c|c|c|c|c|c|}
\hline \multicolumn{5}{|c|}{ SPECIFICATION AND MECHANICAL PROPERTY OF PDO MONOFILAMENT } \\
\hline \multirow{2}{*}{ Sample } & $\begin{array}{c}\text { Diameter } \\
(\mathbf{m m})\end{array}$ & $\begin{array}{c}\text { Linear } \\
\text { density (dtex) }\end{array}$ & $\begin{array}{c}\text { Tensile property } \\
\text { (cN/dtex) }\end{array}$ & $\begin{array}{c}\text { Elongation } \\
(\%)\end{array}$ & $\begin{array}{c}\text { Bending stiffness } \\
\left(\mathbf{c N} \cdot \mathbf{c m}^{2}\right)\end{array}$ \\
\hline PDO-1 & 0.16 & 327.5 & $3.69 \pm 0.18$ & $48.11 \pm 2.29$ & 0.0511 \\
\hline PDO-2 & 0.23 & 631.2 & $3.55 \pm 0.33$ & $47.62 \pm 3.14$ & 0.2036 \\
\hline PDO-3 & 0.29 & 958.7 & $3.5 \pm 0.18$ & $48.11 \pm 2.29$ & 0.4218 \\
\hline
\end{tabular}




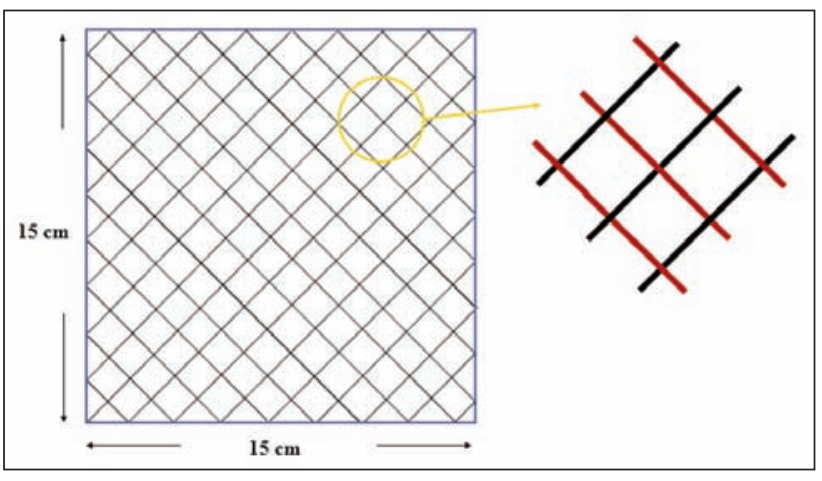

Fig. 3. Design structure of rhombus-pore PDO mesh

$15 \mathrm{~min}$. The number and specifications of PDO meshes prepared in this work were summarized in table 2.

Table 2

\begin{tabular}{|c|c|c|c|}
\hline \multicolumn{4}{|c|}{ SPECIFICATION OF SEVERAL PDO MESHES } \\
\hline Sample & Material & $\begin{array}{l}\text { Pore } \\
\text { shape }\end{array}$ & $\begin{array}{l}\text { Pore } \\
\text { size }\end{array}$ \\
\hline PM-S-1.1 & PDO-1 $0.16 \mathrm{~mm}$ & \multirow{6}{*}{ Square } & \multirow{3}{*}{$5 \mathrm{~mm} \times 5 \mathrm{~mm}$} \\
\hline PM-S-1.2 & PDO-2 $0.23 \mathrm{~mm}$ & & \\
\hline PM-S-1.3 & PDO-3 $0.29 \mathrm{~mm}$ & & \\
\hline PM-S-2.1 & PDO-1 $0.16 \mathrm{~mm}$ & & \multirow{3}{*}{$10 \mathrm{~mm} \times 10 \mathrm{~mm}$} \\
\hline PM-S-2.2 & PDO-2 $0.23 \mathrm{~mm}$ & & \\
\hline PM-S-2.3 & PDO-3 $0.29 \mathrm{~mm}$ & & \\
\hline PM-R-1.1 & PDO-1 $0.16 \mathrm{~mm}$ & \multirow{6}{*}{ Rhombus } & \multirow{3}{*}{$5 \mathrm{~mm} \times 5 \mathrm{~mm}$} \\
\hline PM-R-1.2 & PDO-2 $0.23 \mathrm{~mm}$ & & \\
\hline PM-R-1.3 & PDO-3 $0.29 \mathrm{~mm}$ & & \\
\hline PM-R-2.1 & PDO-1 $0.16 \mathrm{~mm}$ & & \multirow{3}{*}{$10 \mathrm{~mm} \times 10 \mathrm{~mm}$} \\
\hline PM-R-2.2 & PDO-2 $0.23 \mathrm{~mm}$ & & \\
\hline PM-R-2.3 & PDO-3 $0.29 \mathrm{~mm}$ & & \\
\hline
\end{tabular}

\section{Assessment of PDO mechanical property}

Before measurements, all samples were balanced under a standard environment $\left(20^{\circ} \mathrm{C} \pm 2^{\circ} \mathrm{C}, 65 \% \pm 2 \%\right)$ for 24 hours. Each sample was measured for 3 times and took the average for final value.

(1) Surface density

Sample was weighed by FA2004 electronic analytical balance. The surface density was calculated according to equation 1 .

$$
w=m / s
$$

where $m$ refers to sample weight, $s$ refers to sample area.

(2) Thickness

Samples with size of $150 \mathrm{~mm} \times 150 \mathrm{~mm}$ were measured using YG141N fabric thickness tester (Hong Daexperimental Equipment Co., Ltd, China). Pressure was set as $1 \pm 0.01 \mathrm{KPa}$ and last for $30 \pm 5 \mathrm{~s}$.

(3) Bending stiffness

The stiffness was measured according to Standard $\mathrm{GB} / \mathrm{T}$ 18318-2001. Sample was cut into rectangle size of $25 \mathrm{~mm} \times 120 \mathrm{~mm}$ and tested using LLY-01
Fabric Stiffness Tester (Lai Zhou Instruments Co. Ltd, China). Each sample was tested twice one both sides and took the average. The bending stiffness was calculated using the following equation.

$$
G=a \times c^{3} \times 10^{-3}
$$

Where a refers to sample surface density, $c(\mathrm{~cm})-$ sample bending length.

(3) Tensile strength

Sample was cut into $25 \mathrm{~mm} \times 120 \mathrm{~mm}$ rectangle size, measured under HD026N+ electronic strength tester for tensile strength testing (Hong $\mathrm{Da}$ experimental Equipment Co., Ltd, China). Each sample was draw at speed of $100 \mathrm{~mm} / \mathrm{min}$ from a distance of $90 \mathrm{~mm}$ between two chucks, the pre-tension was $3 \mathrm{~N}$.

(4) Bursting strength

Sample with size of $60 \mathrm{~mm} \times 60 \mathrm{~mm}$ circle was measured according to GB/T 19976-2005, also using $\mathrm{HD} 026 \mathrm{~N}+$ electronic strength tester. The initial distance between two chucks was $300 \mathrm{~mm}$, the descend speed was $100 \mathrm{~mm} / \mathrm{min}$.

\section{(5) Suture pulling out force}

Sample with size of $30 \mathrm{~mm} \times 30 \mathrm{~mm}$ square was measured under $\mathrm{YG}(\mathrm{B}) 026 \mathrm{H}-500$ textile multi-function strength tester. The initial distance between sample and chuck was $100 \mathrm{~mm}$, the pre-tension was $0.1 \mathrm{~N}$. Suture was threaded through sample about $3 \mathrm{~mm}$ from edge, draw to breakage at $100 \mathrm{~mm} / \mathrm{min}$. Each sample was measured for 3 times and took the average for final value.

\section{Assessment of PDO in vitro degradation property}

The nutrient solution for degradation test was PH7.2 phosphate buffered solution (PBS) saved under $37^{\circ} \mathrm{C}$. It contained $\mathrm{KCL}(0.2 \mathrm{~g} / \mathrm{l}), \mathrm{NaCl}(8 \mathrm{~g} / \mathrm{L})$, $\mathrm{Na}_{2} \mathrm{HPO}_{4} \cdot 12 \mathrm{H}_{2} \mathrm{O}(2.9 \mathrm{~g} / \mathrm{L})$, and $\mathrm{KH}_{2} \mathrm{PO}_{4}(0.2 \mathrm{~g} / \mathrm{L})$. Sample degradation was mainly decided by material type, therefore only 3 samples with different diameter PDO monofilament composition (PM-S-1.1, PM-S-1.2, PM-S-1.3) were taken into degradation test. Before test, mesh was immersed in anhydrous alcohol, cleaned by deionized water and finally dried in lyophilizer for 2 hours. The dried sample was immersed in PBS solution and cultured in $37^{\circ} \mathrm{C}$ incubator during the whole experiment. The solution was changed each week and sustained for 16 weeks. Samples were taken out each two weeks, dried to a constant weight before measurement. Weight loss weight was calculated according to the following equation.

$$
\text { Weight loss weight }=\left(W_{0}-W_{1}\right) / W_{0} \times 100 \%
$$

Where $W_{0}$ is sample weight before degradation, $W_{1}$ - sample weight after degradation.

\section{RESULTS AND DISCUSSION}

\section{Analysis of PDO monofilaments' mechanical property}

The PDO meshes were fabricated using 3 kinds of PDO monofilaments with diameter ranging from $0.16 \mathrm{~mm}$ to $0.29 \mathrm{~mm}$. The mechanical properties of 
PDO monofilaments were summarized in table 3 . Even with different diameter, 3 types of monofilaments still have similar bursting strength and elongation at break. Moreover, they are stronger than most other polymer monofilaments, with strength larger than $30 \mathrm{cN} \cdot$ tex $^{-1}$ and elongation larger than $45 \%$. PDO macromolecular has good regularity, resulting in its higher degree of crystallinity and orientation after being spun to filaments. The superiority could strength the whole mesh's bursting strength and support prolapsed organs stably [9].

The large amounts of enter linkage in PDO macromolecular is able to increase its flexibility, manifest as high elongation rate. This would lead to a slightly growing strength, reduced initial modulus with the increase of monofilament diameter.

From table 3, it was found that the thicker monofilament had larger stiffness. Stiffness was related to monofilament equivalent flexural modulus and inertia moment. Equivalent flexural modulus is a material nature mainly decided by molecular structure, while inertia moment is decided by monofilament diameter and cross-section shape. The inertia moment of PDO monofilaments used in this experiment was growing along with the increased diameter in compression, leading to a higher stiffness.

\section{Effect of monofilament diameter on PDO mesh}

Table 4 presents three PDO meshes' structural parameters and mechanical properties. The adopted 3 samples have same pore size and pore shape, but different diameter filaments composition. The effect of monofilament diameter on mesh property was analyzed after then.

PDO mesh's surface density and thickness were significantly growing along with the increase of monofilament diameter. The diameter's effect on mesh stiffness and tensile strength was much obvious, mesh became stiffer and stronger when used a thicker monofilament in mesh preparation. Because of the mixing effect of glue addition around filament bonding point, the relationship of diameter and mesh suture pulling out force was unclear. Although, there is no particular law between diameter and bursting strength that sample PM-S-2.3 had significantly advantage in bursting property.

Overall, larger diameter would make mesh be heavier, stiffer and stronger. However, the consequents were unexpected for human sensation after implantation. The softness, lightweight and flexibility were the future development of medical mesh. Based on that, sample PM-S-2.2 with the largest suture pulling out force, moderate surface density was considered of an optimal choice. PDO monofilament with diameter of $0.23 \mathrm{~mm}$ was adopted for the following study.

\section{Effect of pore-shape on PDO mesh}

After discussion of monofilament diameter's effect, the $0.23 \mathrm{~mm}$ was considered to bean optimal choice. Table 5 presents samples consisted of $0.23 \mathrm{~mm}$ monofilaments, but designed to different poreshapes. The effect of pore-shape on mesh property could be studied.

Mesh samples with same pore-size but different pore-shape (PM-S-1.2 VS PM-R-1.2, PM-S-2.2 VS PM-R-2.2) were compared in this experiment. Poreshape was proved to have little effect on mesh surface density, thickness and bursting strength. However, bending stiffness, tensile strength and suture pulling out force were largely influenced. Rhombus-pore shape lead mesh to have small tensile strength but large suture pulling out force. Differently, square-pore shape decided mesh to have a small suture pulling out force but large tensile strength. However, the influence of pore shape on bending stiffness was unclear.

Two groups of samples had different pore shape but the same pore size and material composition. Therefore, the meshes had same density leading to similar mesh thickness and weight. And also, compared with tensile strength, bursting strength was

Table 3

\begin{tabular}{|c|c|c|c|c|}
\hline \multicolumn{5}{|c|}{ MECHANICAL PROPERTY OF PDO MONOFILAMENTS } \\
\hline Sample & $\begin{array}{c}\text { Elongation at break } \\
(\mathbf{\%})\end{array}$ & $\begin{array}{c}\text { Bursting strength } \\
\left(\mathbf{c N} \cdot \mathbf{t e x}^{-1}\right)\end{array}$ & $\begin{array}{c}\text { Initial modulus } \\
\left(\mathbf{N} \cdot \mathbf{t e x}^{-\mathbf{1}}\right)\end{array}$ & $\begin{array}{c}\text { Bending stiffness } \mathbf{G} \\
(\mathbf{c N} \cdot \mathbf{c m})\end{array}$ \\
\hline PDO-1 & 45.334 .12 & 35.683 .42 & 1.220 .11 & 0.0511 \\
\hline PDO-2 & 44.813 .86 & 36.492 .05 & 1.190 .06 & 0.2036 \\
\hline PDO-3 & 47.904 .47 & 38.191 .93 & 1.160 .10 & 0.4218 \\
\hline
\end{tabular}

STRUCTURAL AND MECHANICAL PROPERTIES OF PDO MESHES WITH DIFFERENT DIAMETERS

\begin{tabular}{|c|c|c|c|c|c|c|}
\hline Sample & $\begin{array}{c}\text { Surface density } \\
\left(\mathbf{g} \cdot \mathbf{m}^{-2}\right)\end{array}$ & $\begin{array}{c}\text { Thickness } \\
(\mathbf{m m})\end{array}$ & $\begin{array}{c}\text { Stiffness } \\
(\mathbf{m} \mathbf{N} \cdot \mathbf{c m})\end{array}$ & $\begin{array}{c}\text { Tensile strength } \\
(\mathbf{N})\end{array}$ & $\begin{array}{c}\text { Bursting } \\
\text { strength (N) }\end{array}$ & $\begin{array}{c}\text { Suture pulling } \\
\text { out force }(\mathbf{N})\end{array}$ \\
\hline PM-S-2.1 & 7.260 .32 & 0.540 .05 & 0.210 .01 & 15.421 .12 & 9.430 .72 & 1.380 .10 \\
\hline PM-S-2.2 & 13.510 .10 & 0.590 .04 & 2.090 .12 & 17.681 .60 & 7.140 .52 & 2.450 .20 \\
\hline PM-S-2.3 & 16.840 .15 & 0.720 .05 & 2.420 .15 & 40.442 .87 & 16.751 .15 & 1.510 .08 \\
\hline
\end{tabular}


STRUCTURAL AND MECHANICAL PROPERTIES OF PDO MESHES WITH DIFFERENT PORES

\begin{tabular}{|c|c|c|c|c|c|c|}
\hline Sample & $\begin{array}{c}\text { Surface density } \\
\left(\mathbf{g} \cdot \mathbf{m}^{-\mathbf{2}} \mathbf{)}\right.\end{array}$ & $\begin{array}{c}\text { Thickness } \\
(\mathbf{m m})\end{array}$ & $\begin{array}{c}\text { Stiffness } \\
(\mathbf{m N} \cdot \mathbf{c m})\end{array}$ & $\begin{array}{c}\text { Tensile strength } \\
\mathbf{( N )}\end{array}$ & $\begin{array}{c}\text { Bursting } \\
\text { strength }(\mathbf{N})\end{array}$ & $\begin{array}{c}\text { Suture pulling } \\
\text { out force }(\mathbf{N})\end{array}$ \\
\hline PM-S-1.2 & 28.21 .30 & 0.650 .02 & 38.53 .19 & 23.801 .55 & 12.80 .71 & 2.630 .12 \\
\hline PM-S-2.2 & 15.11 .07 & 0.570 .04 & 2.270 .18 & 13.781 .32 & 6.840 .42 & 1.470 .08 \\
\hline PM-R-1.2 & 27.31 .78 & 0.690 .03 & 38.62 .27 & 7.560 .57 & 13.61 .09 & 3.680 .22 \\
\hline PM-R-2.2 & 13.030 .82 & 0.590 .03 & 4.160 .32 & 6.110 .50 & 7.020 .61 & 1.960 .12 \\
\hline
\end{tabular}

used to characterize overall strength of mesh, not affected by testing direction, mainly relied on mesh density, material's specification.

When testing mesh tensile strength, drawing point concentrated on bonding area. The two monofilaments forming rhombus-pore shape were bonded by medical glue, its force was much less than that of monofilament itself. Therefore, the tensile strength of square pore-shape mesh was much smaller than that of rhombus mesh. However, the square pore-shape brought about a small suture pulling out force for medical mesh, the different was not such significant. Based on that, square pore-shape was considered to be superior to rhombus pore-shape.

\section{Effect of pore-size on PDO mesh}

The relationship between pore- size and mesh property could be obtained from table 5 . Two groups (PM-S-1.2 VS PM-S-2.2 and PM-R-1.2 VS PM-R2.2) were compared. Along with the pore-size increase, mesh's surface density, thickness, bending stiffness, tensile strength, bursting strength and suture pulling out force all reduced. PDO mesh could be lighter and thinner, but also weaker in strength. However, the mesh only decreased $0.1 \mathrm{~mm}$ in thickness property, but largely reduced in strength property when pore-size increased from $5 \mathrm{~mm}$ to $10 \mathrm{~mm}$. PDO mesh's thickness mainly depended on consisted monofilament's diameter. The selected PDO mesh in table 5 were all composed of $0.23 \mathrm{~mm}$ monofilament, as a result, the meshes had similar thickness values.

The fabricated PDO meshes in this work all had extremely low weight, even satisfied requirements of ultra-lightweight mesh $\left(<35 \mathrm{~g} / \mathrm{m}^{2}\right)$ [10]. However, the resulting decline in mesh strength is unexpected. Overall, the sample PM-S-1.2 with square poreshape and $5 \mathrm{~cm}$ pore-size were regarded as more suitable for application in repairing tissue defects.

\section{In vitro degradation property of PDO mesh}

Figure 4 shows weight loss rate of three PDO meshes consisted of different monofilament sizes. It can be found that meshes all degraded slowly in the first 10 weeks and then fast, with weight loss rate reaching to $30 \%$ in the $16^{\text {th }}$ week. In the initial stage of degradation, the ester linkage in PDO backbone was hydrolytic broken, releasing small molecules into the nutrient solution, leading to a slow decrease in weight loss. After then, more generated hydroxyl appeared, resulting in autocatalysis, a much more obvious of degradation phenomenon was discovered.

Among samples with different monofilament size, the PM-S-1.1 had significantly fast degradation speed. The small diameter of monofilaments with large specific surface area made sample to be fully immersed into cultured solution. The molecule chain could be more easily attacked to breakage under hydrolysis, clear evidence of weight loss could be observed.

Overall, PDO meshes had superior degradation property. PDO macromolecular chain is gradually degraded to small molecules which are swallowed by tissue cell, absorbed or excreted to the outside of the body along with metabolism. In the last step of repair, the weight loss of PDO mesh in patient body is good for relieving foreign body sensation, improve life quality.

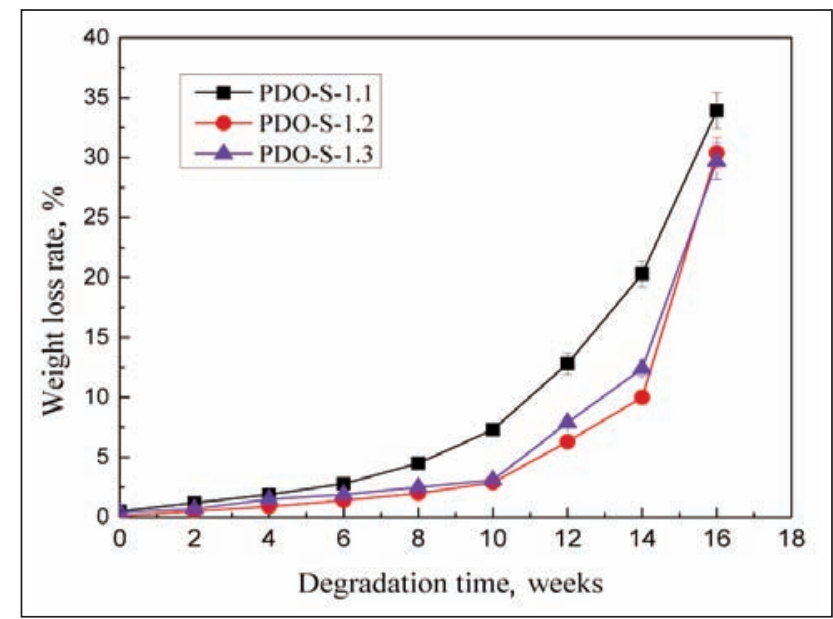

Fig. 4. Weight loss rate of PDO meshes in vitro degradation property

\section{Comprehensive evaluation of PDO mesh}

Figure 5 and figure 6 summarize structural parameters and mechanical properties of five commercial PP meshes, respectively [11-13]. Among them, Marlex ${ }^{\circledR}$ from US Bard Corp is a heavyweight type mesh (>90 $\mathrm{g} / \mathrm{m}^{2}$ ), Prolenesoft ${ }^{\circledR}$ and Gynemesh ${ }^{\circledR}$ from Ethicon are lightweight types $\left(50 \sim 35 \mathrm{~g} / \mathrm{m}^{2}\right)$, Polyform Lite ${ }^{\circledR}$ provided by Marlboroug and Restorelle ${ }^{\circledR}$ mesh from AU Coloplast Corp are both ultra-lightweight types $\left(50 \sim 35 \mathrm{~g} / \mathrm{m}^{2}\right)$. Because of the limited information available, some important structural parameters could not be obtained, e.g. porosity of Marlex ${ }^{\circledR}$ and prolene soft ${ }^{\circledR}$. And also, properties such as stiffness 

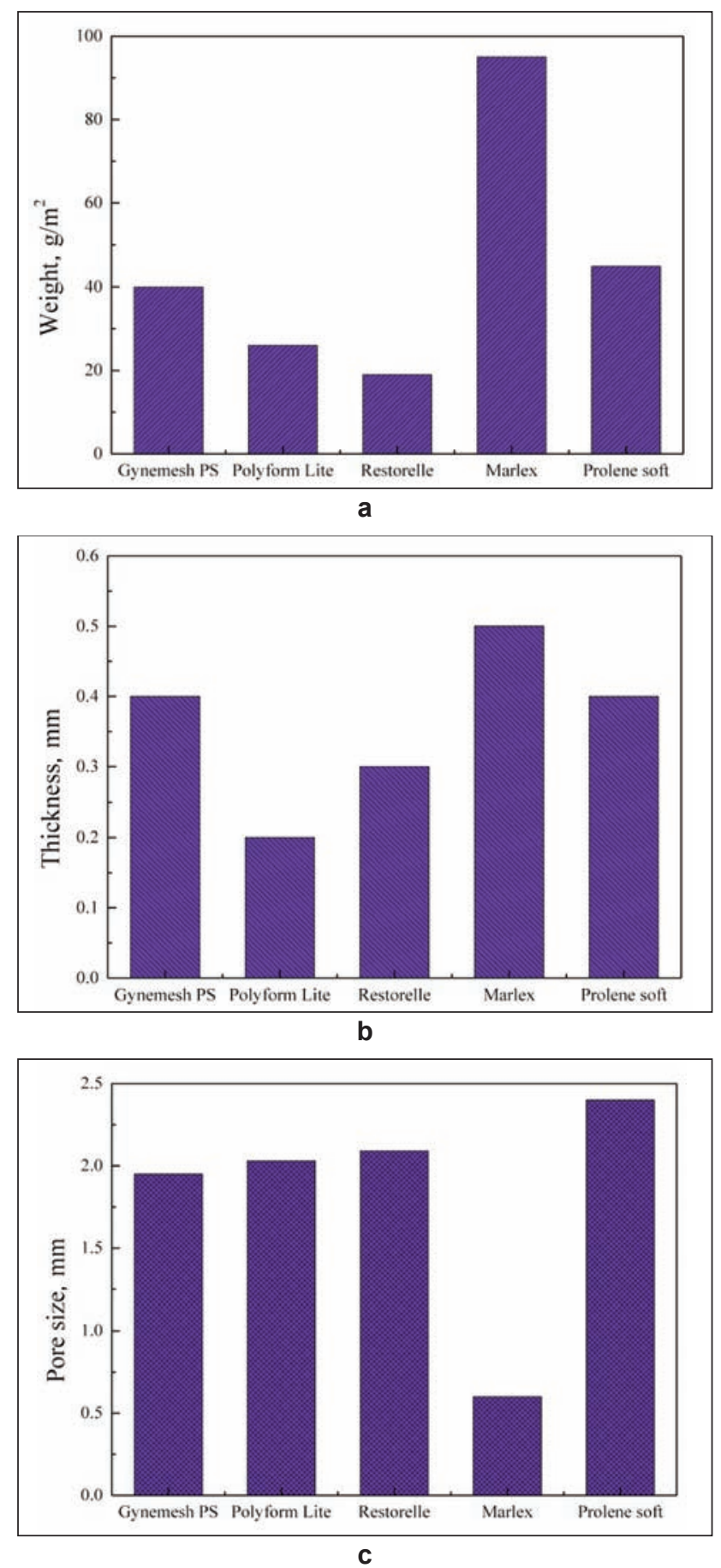

Fig. 5. Structural parameters of 5 commercial meshes: $a$ - weight; $b$ - thickness; $c$ - pore size

and breaking strength of Gynemesh ${ }^{\circledR}$ could only be determined within a scope instead of an accurate value.

By comparison to the above mentioned commercial mesh, PDO mesh is considered to have obvious weight advantage (figure 5,a). The fabricated PDO mesh in this work had weight ranging from $7.3 \mathrm{~g} / \mathrm{m}^{2}$ to $28.0 \mathrm{~g} / \mathrm{m}^{2}$, the extremely little retention of material in human body could relieve discomfort sensory. However, the thickness of PDO mesh (0.59 0.71 $\mathrm{mm}$ ) was much larger than that of PP mesh (less than $0.5 \mathrm{~mm}$ ), (figure $5, b)$. This is related to the large diameter PDO monofilament $(0.16 \sim 0.29 \mathrm{~mm})$ used in this work while PP monofilament used in commercial
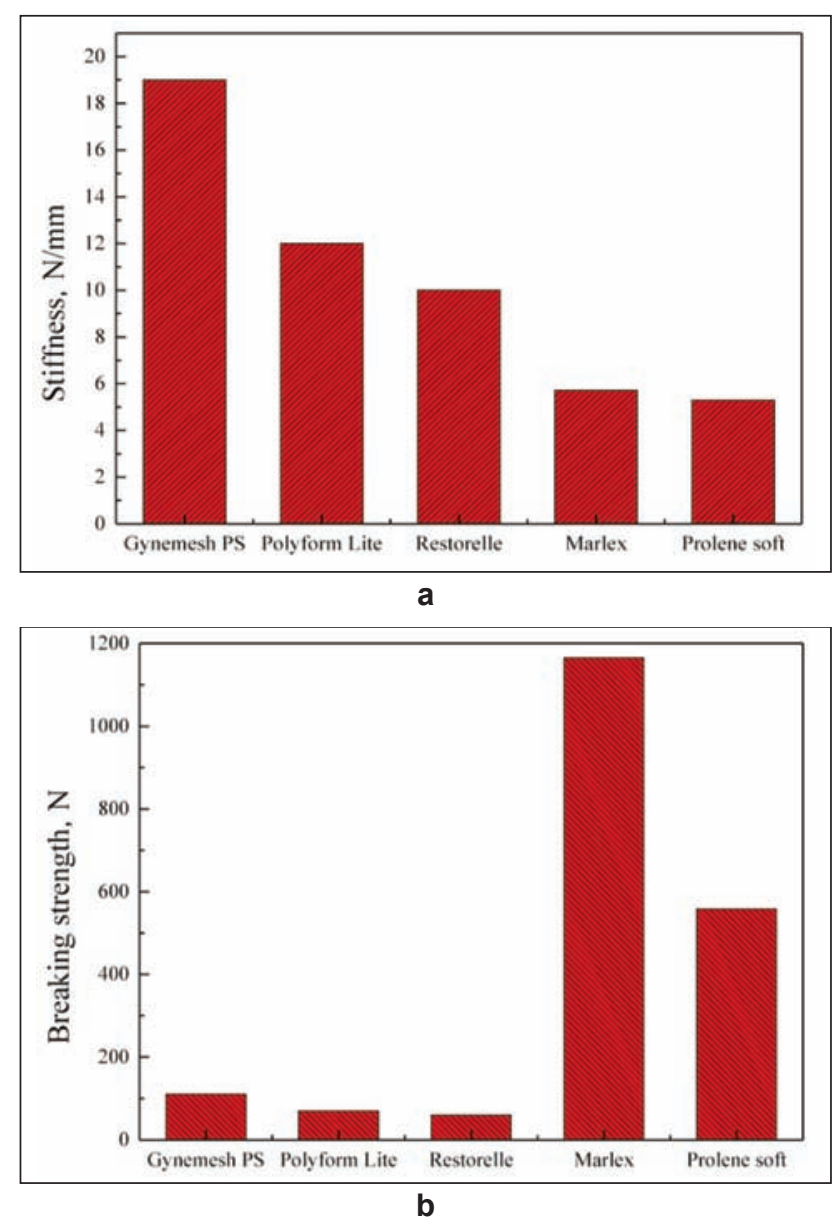

Fig. 6. Mechanical properties of 5 commercial meshes: $a$ - stiffness; $b$ - breaking strength

mesh were $0.08 \mathrm{~mm}$ (Polyform Lite ${ }^{\circledR}$ ) or $0.10 \mathrm{~mm}$ (Polyform Lite ${ }^{\circledR}$ ).

There is no comparability between PDO mesh's stiffness and PP mesh's because of the adopted different measurement method (figure 6, a). Strong contradiction also existed among PP mesh's stiffness itself, e.g. heavier Marlex ${ }^{\circledR}$ mesh's stiffness was reported to be much smaller than that of most lightweight meshes. Even more, the same type product was reported to be different stiffness in different reviews. The nonuniform measuring method and index used leading to the difficulty in evaluating mesh stiffness.

The PDO mesh's breaking strength was much smaller than that of PP mesh (figure $6, b$ ). Mesh strength are related to several parameters, such as mesh weight and material type. The strength of heavyweight mesh is always larger than that of lightweight mesh using the same type material.

Overall, PDO mesh has advantage of ultra-lightweight, but the resulting weak strength limited its application. Different to hernia mesh's replacement to the original tissue, pelvic floor mesh mostly supported or reinforced the weak tissues. Large strength is not a primary requirement for pelvic floor mesh, lightweight and high porosity could improve its effect.

\section{CONCLUSION}

Three types of PDO monofilaments with different diameter were used for mesh preparation in this 
work. The effect of monofilament property, mesh pore-shape and pore-size were discussed for optimize PDO mesh fabrication process. Monofilament diameter of $0.23 \mathrm{~mm}$ was considered to be the most suitable choice based on the balance between weight and strength. Square-pore shape made PDO mesh to have extremely larger tensile strength. Although pore-size of $10 \mathrm{~mm}$ lead mesh to be lighter, the resulted significantly reduced strength was unexpected. By comparison to some widely-used commercial meshes, PDO mesh was assessed to have ultralightweight advantage. However, its application in repairing pelvic floor defects needs more clinical study in future.

\section{ACKNOWLEDGEMENTS}

This study was funded by Ningbo Natural Science Fund (Grant No. 2018A610116), Zhejiang Provincial public welfare technology application \& research plan (Grant No. LGG18E030006), and foundation of Inner Mongolia Scientific Research of University (No. NJZY18095).

\section{BIBLIOGRAPHY}

[1] Özdemır, Ö. Ç., Bakar, Y., Özengın, N., et al. The effect of parity on pelvic floor muscle strength and quality of life in women with urinary incontinence: a cross sectional study, In: Journal of Physical Therapy Science, Jul 2015, vol. 27, no. 7, pp. 2133-2137.

[2] Novitsky, Y., Harrell, A. J., Paton, B., et al. Comparative evaluation of adhesion formation, strength of in growth, and textile properties of prosthetic meshes after long-term intra-abdominal implantation in a rabbit. In: Journal of Surgical Research, Jun 2007, vol .140, no. 1, pp. 6-11.

[3] Hilde, G., Stær-Jensen, J., Siafarikas, F., et al. Impact of childbirth and mode of delivery on vaginal resting pressure and on pelvic floor muscle strength and endurance, In: American Journal of Obstetrics and Gynecology, Oct 2013, vol. 208 , no. 1 , pp. $1-7$

[4] Costantini, E., Lazzeri, M., Bini, V., et al. Pelvic organ prolapse repair with and without prophylactic concomitant burchcolpo suspension in continent women: A randomized, controlled trial with 8-year follow up.In: Journal of Urology. Jun 2011, vol.185, pp. 2236-2240.

[5] Brown, C. N., Finch, J. G. Which mesh for hernia repair?, In: Annals of the Royal College of Surgeons of England, May 2010, vol. 92, no. 4, pp. 272-278.

[6] Junyao, C., Tianhui, W., Deng, D., et al. The degradation property of a Netty Structure Scaffold Reinforcement for Tendon Tissue Engineering, In: Journal of Donghua University (Natural Science), Oct 2010, vol. 36, no. 5, pp. 491-495.

[7] Gemma, P., Belén, H. G., Marta, R., et al. The long-term behavior of lightweight and heavyweight meshes used to repair abdominal wall defects is determined by the host tissue repair process provoked by the mesh, In: Surgery, May 2012, vol. 152, no. 5, pp. 886-895.

[8] Lu Y., Chen Y C., Zhang P. H., Effects of porosity on structure and performance of PP meshes for repairng pelvic floor defects. In: Journal of DonghuaUniversity (English Edition), May 2014, vol. 31, no. 5, pp. 704-708.

[9] Liang, R., Abramowitch, S., Knight, K., et al. Vaginal degeneration following implantation of synthetic mesh with increased stiffness, In: Bjog-Int J ObstetGy, Jan 2013, vol. 120, no. 2, pp. 233-43.

[10] Deeken, C. and Matthews, B. Comparison of contracture, adhesion, tissue in growth, and histologic response characteristics of permanent and absorbable barrier meshes in a porcine model of laparoscopic ventral hernia repair, In: Jul Hernia, 2012, vol. 16, no. 1, pp. 69-76.

[11] Klosterhalfen, B., Junge, K., Klinge, U. The lightweight and large porous mesh concept for hernia repair, In: Expert Review of Medical Devices, 2005, vol. 2, no. 1, pp. 103-17.

[12] Ulrich, D., Edwards, S. L., Alexander, D. L., et al. Changes in pelvic organ prolapse mesh mechanical properties following implantation in rats, In: American Journal of Obstetrics \& Gynecology, 2015, vol. 214, no. 2, pp. 260.e1-260.e8.

[13] Pott, P. P., Schwarz, M. L. R., Ralf, G., et al. Mechanical properties of mesh materials used for hernia repair and soft tissue augmentation, In: Plos One, 2012, vol. 7, no. 10, pp. 4821-4836.

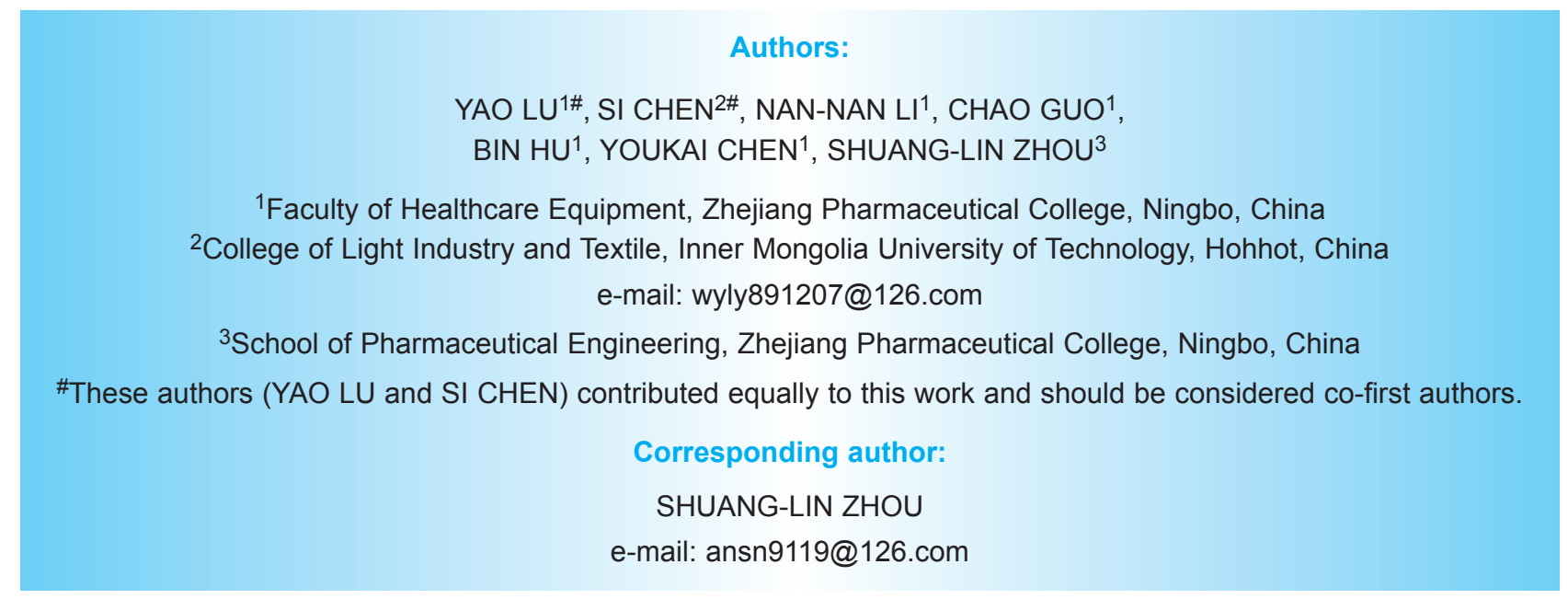

